\title{
KOMENTAR ZAKONIKA O KRIVIČNOM POSTUPKU
}

\section{Poštovane koleginice i kolege,}

velika mi je čast i zadovoljstvo što imam priliku da u svojstvu korecenzenta pred ovim uvaženim skupom kažem nekoliko reči o Komentaru ZKP i njegovim autorima, našim kolegama, prof. dr Goranu Iliću, dr Miodragu Majiću, dr Slobodanu Beljanskom i mr Aleksandru Trešnjevu.

Pred dilemom da li da prvo govorim o autorima ili o Komentaru, opredelio sam se da, na početku, kažem nekoliko reči o autorima, jer kvalitet ovog Komentara još jedna je potvrda onoga što ću o autorima reći.

Pre svega, radi se o uvaženim i uglednim imenima pravničke profesije, sa zavidnim teorijskim i praktičnim iskustvom u krivičnopravnoj oblasti. Kompetentnost autora i njihov dosadašnji doprinos krivičnopravnoj teoriji i praksi, mogu slobodno reći, spada u red notornih činjenica. Kolege Ilić, Beljanski i Majić bili su ujedno članovi radne grupe koje je sačinila Nacrt zakonika o krivičnom postupku. I to ne pasivni članovi, već članovi čiji je doprinos prepoznatljiv, kako u pojedinim delovima zakonskog teksta, tako i u aktivnom učešću u tumačenju novog koncepta zakonika i njegovih odredbi tokom javne rasprave, ali i nakon stupanja Zakonika na snagu i početka njegove primene. Uloga tvoraca zakonskog teksta omogućila je autorima da nas, čitaoce ovog Komentara, na autentičan način, iz prve ruke, upoznaju sa različitim verzijama pojedinih normi, dilemama koje su članovi radne grupe imali, kao i sa razlozima koji su prevagnuli u konačnom opredeljivanju za određeno rešenje. Ovo se naročito odnosi na potpuno nova zakonska rešenja, koja do sada nisu egzistirala u domaćem zakonodavstvu i praksi, što će doprineti njihovom potpunijem razumevanju, omogućavajući njihovu što pravilniju primenu. Ujedno, na taj način pruža se prilika da budu uočene i određene nedoslednosti ili nedovoljno jasna zakonska rešenja, što predstavlja putokaz za njihovu de lege ferenda izmenu ili dopunu.

Moram ovde da iznesem i jedan lični utisak. Tokom nastajanja zakonskog teksta, ali i teksta ovog Komentara, u više navrata imao sam prilike da se neposredno uverim sa kolikim entuzijazmom i posvećenošću su autori pristupali i jednom i drugom poslu. Na takvom pristupu možemo svi da im se zahvalimo, jer pred nama je štivo koje će biti čitano, koje nećemo odlagati na policu da skuplja prašinu, kojem ćemo se vraćati bilo citirajući ga u naučnim i stručnim radovima, bilo primenjujući u praksi odredbe Zakonika o krivičnom postupku. 
Sada bih nešto rekao i o tekstu Komentara, odnosno ZKP-u koji mu je prethodio. Istorijski posmatrano počev od Zakonika o sudskom krivičnom postupku iz 1929. pa do Zakonika čiji Komentar je danas pred nama - bilo je sedam integralnih kodifikacija (1929, 1948, 1953, 1976, 2001, 2005. i 2011). Zakonikom o krivičnom postupku iz 2011. smatram da se čini najveći zaokret do sada, jer se njime prelazi na gotovo čisti angloamerički akuzatorski procesni sistem, sa svim elementima stranačkog modela i raspravnog načela nakon podizanja optužnice. U stručnoj i opštoj javnosti se kao osnovna odlika novog ZKP-a uobičajeno ističe uvođenje tužilačke istrage. Iako ona predstavlja jednu od najprepoznatljivijih novina, ZKP je izraz nastojanja da se, saglasno pravu na pravično suđenje kao temeljnom standardu vladavine prava, dosledno promoviše stranački postupak i nepristrasnost suda, što je nužno imalo za posledicu odustajanje od tradicionalno prihvaćene inkvizitorske uloge suda u utvrđinju činjenica u krivičnom postupku. Usled toga bilo je nužno izmeniti postojeće ili uvesti nove procesne institute, kao što su proširenje mogućnosti nagodbe javnog tužioca i okrivljenog, obavezna sudska kontrola optužnice, pripremno ročište, stavljanje u prvi plan dokazne raspravnosti stranaka na glavnom pretresu, unakrsno ispitivanje svedoka, svođenje ex officio postupanja suda na meru koja ne dovodi u pitanje njegovu nepristrasnost i slično. Kako su i sami autori svojevremeno konstatovali

„Otpor sa kojim je u stručnim krugovima dočekan prelazak na tzv. tužilačku istragu, iako baziran na principijelnom stavu o prednostima sudskog krivičnog postupka u celini, nije bio lišen razloga praktične prirode, proisteklih iz nepoverenja u spremnost javnog tužilaštva da istragu vodi na objektivan način, uz puno poštovanje prava druge strane. Novi model istrage i nova uloga suda u dokazivanju, međutim, logična su posledica novog i odlučujućeg približavanja akuzatorskom postupku i raspravnom načelu. Primena novog Zakonika neće biti laka, i to ne zbog njegove strukture ili nerazgovetnosti njegovog sadržaja, već zbog vrste pravnog obrazovanja, stečenih navika, nedostatka kadrova, a ponajpre zbog sociopsihološkog fenomena koji bismo mogli nazvati nedostatkom kulture nepristrasnosti."

Komentar koji je pred nama, u izdanju „Službenog glasnika”, sadrži ukupno 1128 strana štampanog teksta, od čega 32 strane zauzima registar pojmova, skraćenice sudova i opštih pravnih akata, zatim 6 strana zauzima spisak opštih pravnih akata koje su autori koristili, a sadržaj i spisak literature 22 strane.

Ono što je naročito značajno i na šta bih vam skrenuo posebnu pažnju jeste činjenica da tekst Komentara obiluje domaćom i inostranom sudskom praksom. S obzirom da je Zakonik o krivičnom postupku početkom prošle godine počeo da se primenjuje u postupcima za krivična dela organizovanog kriminala 
i ratnih zločina, obimnija sudska praksa proistekla iz njegove primene još uvek ne postoji. Međutim, većina novih sudskih odluka, donesenih nakon početka primene Zakonika o krivičnom postupku, uvrštena je u tekst Komentara. Pored toga, u Komentaru su sadržane brojne izuzetno aktuelne odluke sudova koje se mogu primeniti u oblastima koje nisu bitnije menjane. Posebno treba istaći da Komentar sadrži praksu Ustavnog suda i Evropskog suda za ljudska prava koja predstavlja referentni okvir za postupanje redovnih sudova u vezi sa standardima ljudskih prava u krivičnom postupku. Sve ovo biće od posebnog značaja za sudije, tužioce i advokate koji će primenjivati ovaj zakonski tekst, naročito zbog toga što u mnogim delovima nije moguće pronaći analogiju sa ranijim zakonskim rešenjima.

Prema načinu pisanja, tekst Komentara je prvenstveno namenjen onima koji će nova zakonska rešenja primenjivati u praksi. Umesto opširnih teorijskih analiza pojedinih pravnih instituta, autori su se opredilili za jezgrovita $\mathrm{i}$ praktična objašenja procesnih situacija i dilema koje mogu nastati u vezi sa primenom određene zakonske odredbe. U značajnom broju slučajeva čitaocu su izloženi različiti stavovi koje je sudska praksa imala o određenom pitanju, uz opredeljivanje autora za onaj, koji prema njihovom mišljenju, ima najviše opravdanja. Ovo, međutim, ne znači da su autori zanemarili i teorijsko sagledavanje određenih pitanja. Ovaj Komentar nudi obilje materijala i čitaocima koji se krivičnim procesnim pravom bave prvenstveno iz ugla teorije, nudeći nov pogled na procesne institute koji do sada nisu bili svojstveni domaćem krivičnom postupku. Vokacije autora, od kojih je jedan advokat, drugi profesor krivičnog procesnog prava i sudija Ustavnog suda, a preostala dvojica sudije krivičari, omogućile su pravilan i uravnotežen pristup materiji u kojem teorijski pogled zauzima onoliko prostora koliko je neophodno za praktičnu primenu Zakonika o krivičnom postupku.

Zbog svega što sam prethodno rekao, mislim da delim uverenje naučne $i$ stručne javnosti, a kao korecenzent sigurno delim uverenje svojih uvaženih kolega Miodraga Simovića i Draga Radulovića, da će ovaj Komentar biti nezaobilazna literatura na pravnim fakultetima, ne samo u Srbiji, već i šire, za pravosudne ispite, za obuku sudija, tužilaca i advokata koja je u toku, a prvenstveno za pravilnu primenu novog Zakonika o krivičnom postupku, kao i za razumevanje novog modela postupka i njegovih posledica u pravosudnom sistemu.

Na kraju, poželeo bih autorima, ali i nama kao čitaocima, nova izdanja ovog Komentara. Pre svega jer sam siguran da tiraž od 300 primeraka neće ni izbliza biti dovoljan da zadovolji aktuelne potrebe naučne i stručne javnosti za ovim štivom. Pored toga, praksa primene novog ZKP-a, pogotovo u redovnim postupcima, pružiće novi materijal autorima za kritičku analizu zakonskog teksta, a samim tim i za dopunu Komentara aktuelnom sudskom praksom, kao i za nova teorijska sagledavanja i objašnjenja. 